\title{
Distribution and Drift of Atlantic Cod (Gadus morhua) Eggs and Larvae in Greenland Offshore Waters
}

\author{
Kai Wieland \\ Greenland Institute of Natural Resources \\ P.O. Box 570, DK 3900 Nuuk, Greenland \\ and \\ Holger Hovgård \\ Danish Institute for Fisheries Research \\ Charlottenlund Slot, DK 2920 Charlottenlund, Denmark
}

\begin{abstract}
Catches of Atlantic cod (Gadus morhua) eggs and larvae from 45 national and international ichthyoplankton surveys conducted in Greenland offshore waters during the period 1950 to 1984 have been compiled and re-analysed. Southeast and Southwest Greenland were identified as important spawning areas from which eggs and early larvae drift towards the southern Davis Strait. Only a part of the larval population remained in the vicinity of favourable settling areas off West Greenland while a considerable part was obviously transported westward across the Davis Strait and thus did not contribute to the recruitment of the West Greenland cod stock. It is also shown that cod eggs and larvae occasionally drift from Southwest Iceland across the Denmark Strait to the East Greenland shelf from where a subsequent transport and immigration of juveniles to West Greenland waters can occur. Larval transport across the Denmark Strait appeared to be most crucial for short-term replenishment of the offshore stock of cod at East and West Greenland. In general, these results confirm the existing knowledge on the transport of cod fry in Greenland waters but they indicate a higher importance of Southeast and East Greenland waters as potential spawning and settling areas for the recruitment of West Greenland cod than reported in previous studies.
\end{abstract}

Key words: Atlantic cod, egg and larval distribution, egg and larval drift, Greenland, spawning location, spawning time

\section{Introduction}

The Atlantic cod (Gadus morhua) population in Greenland waters has shown large variations in abundance and distribution in the past decades. Prior to 1920 annual catches of cod were less than 100 tons and were restricted to inshore areas (Buch et al. 1994). Thereafter a large offshore fishery developed frequently yielding annual catches above 300000 tons through the 1950s to 1960s (Horsted 2000). At the same time, the spawning stock biomass was gradually reduced and the catches declined dramatically in the late-1960s (Hansen and Buch 1986). In the 1970s and 1980s annual catches were generally poor and dependent on single strong year-classes, which gave rise to an intermediate fishery with catches of about 100000 tons in 1988-89. Since then, Atlantic cod has disappeared from the offshore waters (Rätz 1999) and at present only a small inshore fishery takes place (Anon. 2002).

Tagging experiments have indicated that the Atlantic cod found offshore at West Greenland is a mixture of three components originating from spawning locations at East and West Greenland as well as at Iceland (Rasmussen 1959). In addition, relatively stationary populations of Atlantic cod exist in West Greenland inshore areas (Hansen 1949, Hovgård and Christensen 1990).

Migration of Atlantic cod from Greenland offshore waters back to the spawning ground at Iceland has been documented based on tagging experiments (Hovgård and Christensen 1990) and analytical assessments (Shepherd and Pope 1993; Schopka 1993, 1994). 
The occurrence of strong year-classes at West Greenland is linked to egg and larval drift from Icelandic spawning grounds for which the conditions are more favourable in warm than in cold periods (Buch et al. 1994). A substantial increase in water temperature at West Greenland has been observed since the beginning of the 1990s (Buch et al. MS 2002). There are, however, no indications that any relevant advection of cod eggs and larvae from the Icelandic spawning areas has taken place recently as it could be expected from the actual temperature regime (Borovkov and Stein MS 2001; Rätz et al. 1999), and hence the offshore stock of Atlantic cod at West Greenland has not recovered yet (Anon. 2001).

The first studies on the distribution of Atlantic cod fry at West Greenland were conducted at the beginning of the $20^{\text {th }}$ century (Jensen 1909a, 1909b, 1926). Since then, numerous ichthyoplankton surveys were carried out by Danish and Greenland Research Institutions, and also by other nations during the 1960s. An especially large amount of information on the occurrence of eggs and larvae in West and East Greenland waters was collected during the international NORWESTLANT project in 1963 (Anon. 1968). Except for a summary of the ichthyoplankton data collected prior to World War II given in Hansen (1949), the survey results have been published in a very fragmentary way.

It is the objective of the present contribution to compile and analyse the considerable body of information on abundance and distribution of Atlantic cod eggs in Greenland offshore waters collected by various research institutes since 1950. This is done in order to evaluate possible links between the location of spawning and nursery areas and may further provide a basis for modelling the transport of cod eggs and larvae in the Northwest Atlantic.

\section{Material and Methods}

The major source of information used in the present study was derived from a series of plankton surveys carried out by the Greenland and Danish Research Institutes in the years 1950 to 1984 . In addition, original data from the international NORWESTLANT surveys in 1963 were included in the analysis. Further information was extracted from ichthyoplankton surveys conducted by the former German Democratic Republic in the period 1961 to 1969.

The data from the different surveys were grouped into two main seasons, egg surveys in spring includ- ing samples taken from late-March to early-June and larval surveys in summer covering the period from late- May to early-August (Tables 1 and 2). Samples taken outside these periods were not considered in the present analysis. Maps of average egg and larval distributions combining survey results from different years were constructed by dividing the catch from a station by the corresponding annual mean catch. The relative catches were then mapped using ordinary point kriging (Chilès and Delfiner, 1999) with a spatial resolution of 2.5 nautical miles averaging the catches located at the same position for the considered decade, i.e. 1950-60, 1961-70, and 1971-80.

\section{Surveys conducted by Denmark and Greenland}

Danish and Greenland Research Institutes conducted comprehensive egg surveys only in the years 1968 to 1970 while in other years only few stations were sampled in spring (Table 1a). Larval surveys were carried out in summer in most of the years from 1950 to 1984 (Table 1b). The surveys initially covered West Greenland offshore waters between $58^{\circ}$ and $70^{\circ} \mathrm{N}$ but were gradually reduced to shelf areas between $64^{\circ}$ and $67^{\circ} \mathrm{N}$ in the later years.

Catches of cod eggs and larvae as well as corresponding station information have been compiled from the original field journals. The data have been thoroughly scrutinized and hauls with imprecise or unreliable information have been discarded. Over the several decades of surveys various changes in gear operation and rigging were made. It was therefore necessary to select comparable data and to adjust the catches to a common standard; a 30 min haul with a $2 \mathrm{~m}$ Stramin ring net towed obliquely from about 50 $\mathrm{m}$ depth to the surface as described below.

Towing speed and tow duration. Ship velocity was about 1.5 to 2 knots during the whole tow duration and the target towing time was $30 \mathrm{~min}$. Hauls with shorter or longer towing times were adjusted accordingly, while no corrections for differences in towing speed were applied.

Gear size. Ring nets with diameters of 1 and 2 $\mathrm{m}$ both with a mesh size of $1 \mathrm{~mm}$ were used, and all catches were adjusted to a net opening diameter of 2 $\mathrm{m}$. Calibration experiments with a flowmeter mounted in the net opening revealed that a standard haul with the $2 \mathrm{~m}$ Stramin ring net ( $30 \mathrm{~min}$ haul at 2 knots towing speed) equates to a filtered volume of water of about $6125 \mathrm{~m}^{3}$. 
TABLE 1. Sampling dates for Stramin and Hensen net catches of cod eggs and larvae in West Greenland offshore waters 1950-84 (*: within the geographical limits shown in Fig. 4 and 6; GN: Greenland Institute of Natural Resources, GDR: former German Democratic Republic, INT: NORWESTLANT international surveys; see text for references; **: Day of year, weighted for number of samples in the case of combined surveys).

\begin{tabular}{|c|c|c|c|c|c|}
\hline & & Net & Number of & Sampling period* & Survey \\
\hline Year & Source & type & samples & start end & midpoint** \\
\hline
\end{tabular}

a) Spring

\begin{tabular}{|c|c|c|}
\hline 1961 & $\begin{array}{l}\text { GN } \\
\text { GDR }\end{array}$ & $\begin{array}{l}\text { Stramin } \\
\text { Stramin }\end{array}$ \\
\hline 1962 & $\begin{array}{l}\text { GN } \\
\text { GDR }\end{array}$ & $\begin{array}{l}\text { Stramin } \\
\text { Stramin }\end{array}$ \\
\hline 1963 & $\begin{array}{l}\text { GN } \\
\text { INT }\end{array}$ & $\begin{array}{l}\text { Stramin } \\
\text { Stramin } \\
\text { Hensen }\end{array}$ \\
\hline 1965 & GDR & Stramin \\
\hline 1966 & GDR & Stramin \\
\hline 1968 & GN & Stramin \\
\hline 1969 & $\begin{array}{l}\text { GN } \\
\text { GDR }\end{array}$ & $\begin{array}{l}\text { Stramin } \\
\text { Stramin }\end{array}$ \\
\hline 1970 & GN & Stramin \\
\hline
\end{tabular}

6
16
3
36
11
84
35
32
26
21
14
26
16

24 April
02 April
27 March
01 May
17 April
10 April
12 April
07 May
15 April
10 April
16 April
15 May
06 May

27 May

12 April

106

27 March

05 June

134

31 May

31 May

03 June

127

12 May

130

01 May

113

14 May

118

06 May

25 May

132

31 May

139

b) Summer

\begin{tabular}{|c|c|c|c|c|c|c|}
\hline 1950 & GN & Stramin & 56 & 27 May & 23 July & 176 \\
\hline 1952 & GN & Stramin & 35 & 23 June & 31 July & 194 \\
\hline 1953 & GN & Stramin & 43 & 07 June & 25 July & 182 \\
\hline 1954 & GN & Stramin & 63 & 20 June & 31 July & 192 \\
\hline 1955 & GN & Stramin & 43 & 02 June & 30 July & 182 \\
\hline 1956 & GN & Stramin & 30 & 05 June & 1 August & 186 \\
\hline 1957 & GN & Stramin & 35 & 21 June & 23 July & 188 \\
\hline 1958 & GN & Stramin & 42 & 27 June & 25 July & 192 \\
\hline 1959 & GN & Stramin & 33 & 05 June & 25 July & 181 \\
\hline 1960 & GN & Stramin & 24 & 04 July & 28 July & 198 \\
\hline 1961 & GN & Stramin & 33 & 27 May & 30 July & 179 \\
\hline 1963 & $\begin{array}{l}\text { GN } \\
\text { INT }\end{array}$ & $\begin{array}{l}\text { Stramin } \\
\text { Stramin }\end{array}$ & $\begin{array}{r}148 \\
28\end{array}$ & $\begin{array}{l}27 \text { May } \\
\text { 02 June }\end{array}$ & $\begin{array}{l}31 \text { July } \\
11 \text { June }\end{array}$ & 176 \\
\hline 1964 & $\begin{array}{l}\text { GN } \\
\text { GDR }\end{array}$ & $\begin{array}{l}\text { Stramin } \\
\text { Stramin }\end{array}$ & $\begin{array}{l}41 \\
39\end{array}$ & $\begin{array}{l}25 \text { June } \\
22 \text { June }\end{array}$ & $\begin{array}{l}\text { 05 Aug } \\
21 \text { July }\end{array}$ & 194 \\
\hline 1966 & GN & Stramin & 25 & 09 July & 13 July & 192 \\
\hline 1968 & GN & Stramin & 26 & 12 June & 30 July & 188 \\
\hline 1969 & GN & Stramin & 20 & 12 June & 20 June & 167 \\
\hline 1970 & GN & Stramin & 39 & 28 May & 30 July & 180 \\
\hline
\end{tabular}


TABLE 1. (Continued).

\begin{tabular}{|c|c|c|c|c|c|c|}
\hline \multirow[b]{2}{*}{ Year } & \multirow[b]{2}{*}{ Source } & \multirow{2}{*}{$\begin{array}{l}\text { Net } \\
\text { type }\end{array}$} & \multirow{2}{*}{$\begin{array}{c}\text { Number of } \\
\text { samples }\end{array}$} & \multicolumn{2}{|c|}{ Sampling period* } & \multirow{2}{*}{$\begin{array}{l}\text { Survey } \\
\text { midpoint** }\end{array}$} \\
\hline & & & & start & end & \\
\hline & \multicolumn{6}{|c|}{ b) Summer (continued) } \\
\hline 1971 & GN & Stramin & 34 & 14 June & 23 July & 185 \\
\hline 1972 & GN & Stramin & 22 & 13 June & 08 July & 178 \\
\hline 1973 & GN & Stramin & 16 & 21 June & 04 July & 179 \\
\hline 1974 & GN & Stramin & 22 & 26 June & 19 July & 189 \\
\hline 1975 & GN & Stramin & 16 & 05 July & 07 July & 187 \\
\hline 1976 & GN & Stramin & 17 & 06 July & 09 July & 190 \\
\hline 1977 & GN & Stramin & 16 & 07 July & 12 July & 191 \\
\hline 1978 & GN & Stramin & 17 & 10 July & 13 July & 193 \\
\hline 1979 & GN & Stramin & 19 & 13 June & 11 July & 178 \\
\hline 1980 & GN & Stramin & 32 & 05 July & 19 July & 194 \\
\hline 1981 & GN & Stramin & 38 & 02 July & 13 July & 189 \\
\hline 1982 & GN & Stramin & 40 & 05 July & 17 July & 192 \\
\hline 1983 & GN & Stramin & 12 & 01 July & 10 July & 187 \\
\hline 1984 & GN & Stramin & 16 & 06 July & 10 July & 190 \\
\hline
\end{tabular}

Net material. Stramin nets were used in the majority of the hauls, but in a few years during the late1950s some hundreds of hauls were made with nylon netting. Comparative tows of which at least one of the two different nettings yielded non-zero catches revealed no significant difference for the eggs (28 stations) nor for the larvae (18 stations). Hence, the nylon net hauls were included in the analysis without any correction.

Haul method and sampling depth. Since 1950 three different operational procedures were employed, step-wise settings with two or three different wire lengths and oblique hauls:

- Egg surveys in 1961-70: The net was towed for $15 \mathrm{~min}$ with $100 \mathrm{~m}$ wire followed by another $15 \mathrm{~min}$ with $50 \mathrm{~m}$ wire. These wire lengths correspond to sampling depth of 30 and $15 \mathrm{~m}$, respectively (Hansen 1949).
- Larval surveys in 1950-62, 1964 and 1966: Two nets were operated simultaneously on the same wire with a distance of 100 $\mathrm{m}$ wire between. The wire lengths were 200 , 150 and $125 \mathrm{~m}$ for the deeper net, and 100 , 50 and $25 \mathrm{~m}$ for the shallow one. The towing time was $10 \mathrm{~min}$ for each of the three steps. The mean ratio of larval catches obtained with the shallow and the deep net being 1.05 was not statistically different from 1 , and the catches from the two nets of the paired stepwise settings were averaged to match oblique hauls.

- Larval surveys in 1963 and 1968-84: Oblique hauls were made with a maximum wire length of $225 \mathrm{~m}$, which corresponds to a maximum sampling depth of approximately $50 \mathrm{~m}$. 
TABLE 2. Sampling dates for Stramin and Hensen net catches and average number per tow of cod eggs and larvae off East Greenland and Iceland in spring and summer 1963 (*: geographical limits shown in Fig. 8 and 9, **: no Hensen net samples available in this period; average egg and larval catch refer to a 30 min standard tow with a $2 \mathrm{~m}$ Stramin ring net, -: conversion of Hensen net catches not possible).

\begin{tabular}{lccccc}
\hline \hline & $\begin{array}{c}\text { Net } \\
\text { type }\end{array}$ & Number of & Sampling period & \multicolumn{2}{c}{ Average number of } \\
Area* & samples & start & end & cod eggs & cod larvae \\
\hline
\end{tabular}

\begin{tabular}{|c|c|c|c|c|c|c|}
\hline \multirow[t]{3}{*}{ 1. W Iceland } & Stramin & 15 & 18 April & 22 April & 5206.53 & 0.73 \\
\hline & Hensen & 22 & 01 May & 31 May & 991.55 & - \\
\hline & Combined & 37 & 18 April & 31 May & 2700.32 & 0.73 \\
\hline \multirow[t]{3}{*}{ 2. SW Denmark Strait } & Stramin & 20 & 13 April & 21 April & 3.50 & 0.00 \\
\hline & Hensen & 56 & 13 April & 30 May & 5.20 & - \\
\hline & Combined & 76 & 13 April & 30 May & 4.75 & \\
\hline \multirow[t]{3}{*}{ 3. E Greenland } & Stramin & 31 & 09 April & 12 April & 262.10 & 0.00 \\
\hline & Hensen & 27 & 20 April & 28 May & 78.67 & - \\
\hline & Combined & 58 & 09 April & 28 May & 176.71 & - \\
\hline \multirow[t]{2}{*}{ 4. SE Greenland } & Stramin & 0 & & & & \\
\hline & Hensen & 49 & 11 April & 30 April & 1152.41 & - \\
\hline \multicolumn{7}{|c|}{ b) Summer** } \\
\hline 1. W Iceland & Stramin & 15 & 12 July & 19 July & 1.73 & 4.40 \\
\hline 2. SW Denmark Strait & Stramin & 33 & 07 July & 15 July & 0.48 & 6.45 \\
\hline 3. E Greenland & Stramin & 18 & 04 July & 07 July & 4.28 & 0.06 \\
\hline 4. SE Greenland & Stramin & 29 & 24 May & 31 July & 3.79 & 0.24 \\
\hline
\end{tabular}

\section{German Democratic Republic Surveys}

Results from ichthyoplankton surveys carried out by the former German Democratic Republic in West Greenland waters in April/May 1961, 1962, 1965, 1966 and 1969 and in June/July 1964 were used to supplement the existing data set (Table 1). Catches of cod eggs and larvae in numbers-per-haul were directly read from distribution charts given in the reports by Biester and Mahnke (1963), Mahnke (1967a, 1967b) and Ernst (1970) while the station positions were estimated from the figures after adequate magnification. A $2 \mathrm{~m}$ Stramin ring net was used in all of these surveys. The maximum wire length was $200 \mathrm{~m}$ and the net was towed obliquely from its maximum depth to surface for $30 \mathrm{~min}$ at a towing speed of about 2 knots except for 1964 in which the vessel speed was 4 knots due to technical reasons. Hence, the hauling procedure was more or less comparable but not identical to that used during the surveys conducted by Greenland.
However, the data were used in the analysis without any correction assuming that a possible bias due to methodological differences is small compared to other sources of error.

\section{NORWESTLANT surveys}

Catches of cod eggs and larvae from other countries than Denmark and Greenland were taken from the biological data report on the three international NORWESTLANT surveys conducted in 1963 (Anon., 1968). The original survey periods were 31 March to 9 May, 30 April to 30 June, and 30 June to 3 August. The survey area included West and East Greenland offshore waters as well as the western part of the spawning area of cod at Iceland. Samples from 30 min oblique tows with a $2 \mathrm{~m}$ Stramin ring net using a maximum wire length of $225 \mathrm{~m}$ and a towing speed of 2 knots were available for the majority of the survey area, but a significant part of Southeast Green- 
land waters in spring was surveyed using a Hensen net $(72 \mathrm{~cm}$ diameter, hauled vertically from a maximum depth of $100 \mathrm{~m}$ to surface) only (Table 2). However, results from 58 comparative tows with non-zero catches of cod eggs made it possible to convert Hensen net catches to the $2 \mathrm{~m}$ Stramin ring net standard based on a highly significant $(p<0.01) \log$-log regression (Fig. 1) using the following equation:

\section{$\log _{10}($ Stramin net catch of cod eggs $=$}

$1.3834+0.8275 * \log _{10}($ Hensen net catch of cod eggs $)$

A similar approach could not be used for cod larvae due to very low and infrequent catches obtained with the Hensen net.

\section{Results}

\section{Cod eggs and larvae at West Greenland}

Results from spring and summer surveys were available for 8 and 7 years, respectively for the period 1961 to 1970 (Table 1). Average annual egg catches divided by the offshore spawning stock biomass (SSB) of cod at West Greenland (SSB as given in Hansen and Buch, 1986) in the corresponding year indicate a spawning period from mid-March to lateMay (Fig. 2). Maximum egg abundance was found in late-April and almost no cod eggs occurred in June and July. Some cod larvae were observed during the spring surveys but much higher average catches were taken in June and July (Fig. 3).

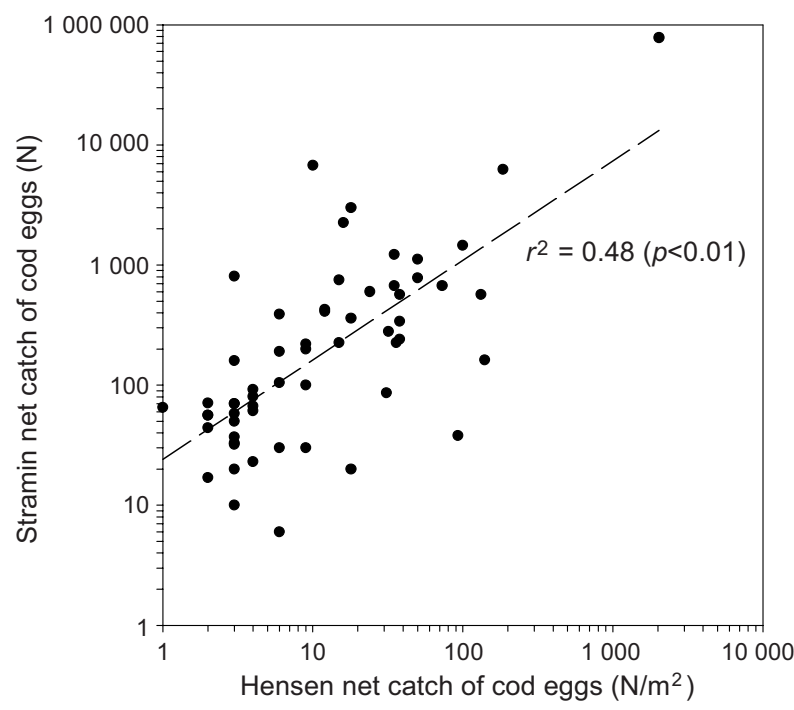

Fig. 1. Comparison of cod eggs catches obtained with $2 \mathrm{~m}$ Stramin ring net and Hensen net.

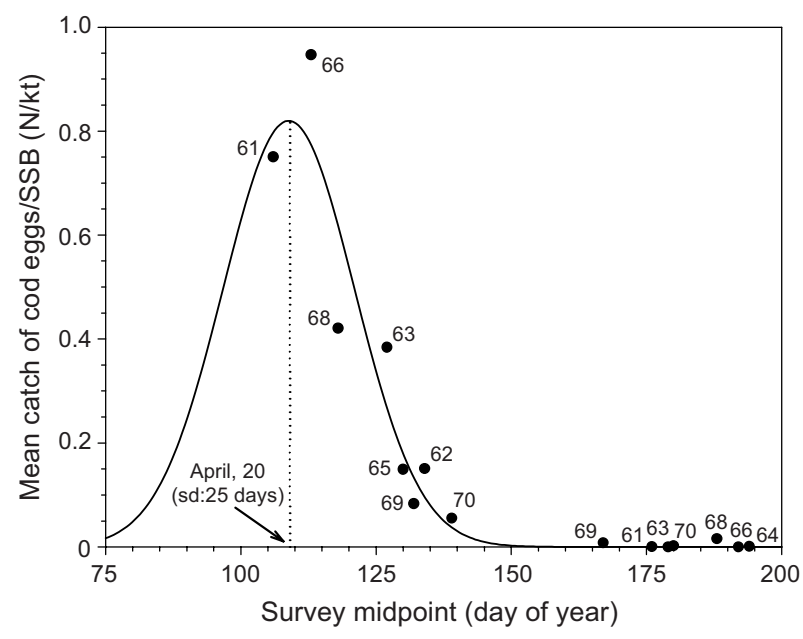

Fig. 2. Timing of cod spawning at West Greenland 196170 (numbers at the symbols refer to years). Gaussian distribution fitted $\left(r^{2}=0.93\right)$ to survey mean catch of cod eggs in NAFO Div. 1B-1F divided by spawning stock biomass (SSB) at West Greenland (offshore stock) of the corresponding year in relation to the survey midpoint (Table 1).

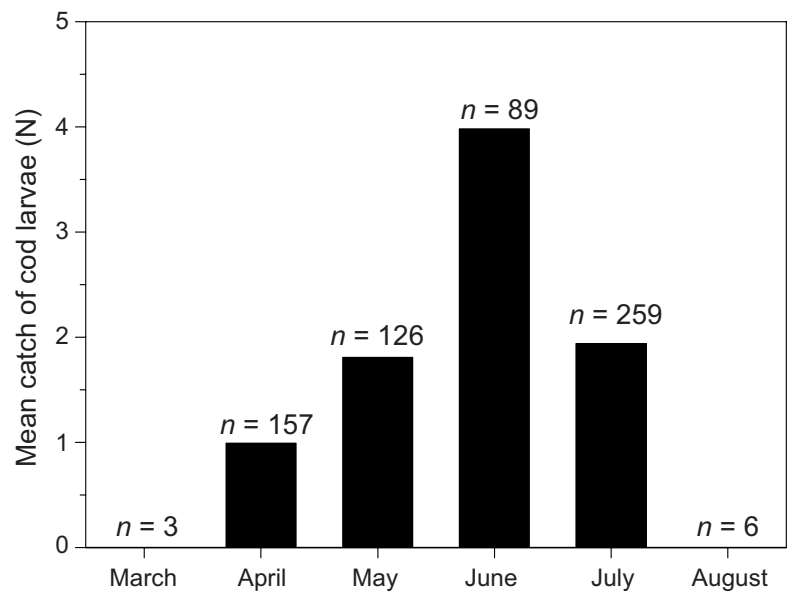

Fig. 3. Mean monthly catch of cod larvae at West Greenland 1961-70 ( $n$ : number of hauls).

Annual distributions of cod eggs in spring are shown in Figure 4 summarizing the results from 12 surveys conducted the years 1961-63, 1965-66, and 1968-70 (Table 1a). Area coverage differed somewhat between the years and it is noteworthy that Southwest Greenland waters, i.e. NAFO Division 1F where the highest egg abundance was observed (e.g.two stations with 3000 to $5000 \mathrm{cod}$ eggs per $30 \mathrm{~min}$. tow in 1963), was covered covered in only two out of the 8 years. However, it appears that during the period considered here cod eggs occurred all along the West 

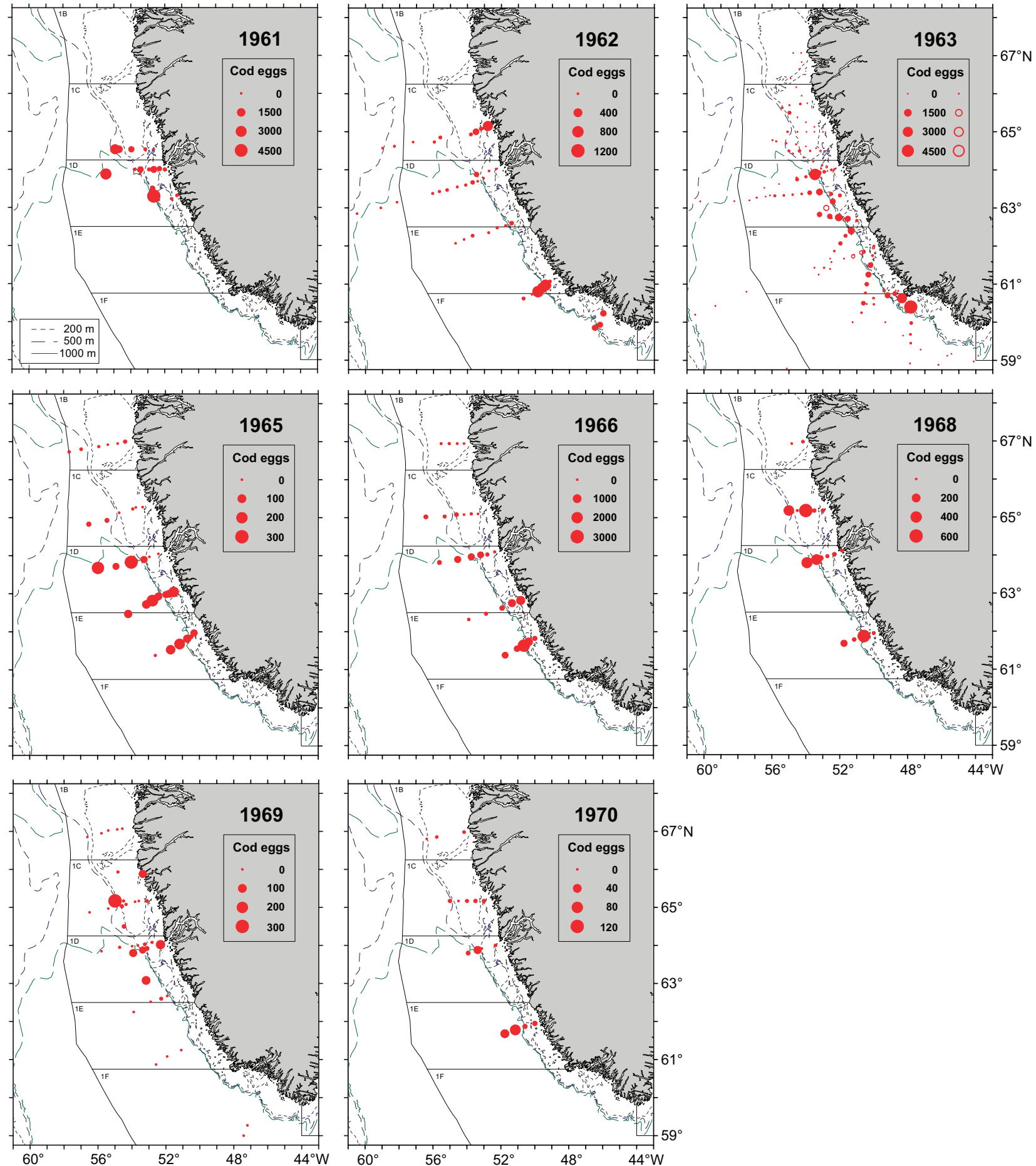

Fig. 4. Distribution of cod eggs in West Greenland offshore waters 1961 to 1970. Egg numbers refer to 30 min haul with 2 m Stramin ring net (open symbols in 1963: Hensen net catches converted to Stramin). Sampling period: late-March to early-June (see Table 1a for details; 1964 and 1967 no data).

Greenland coast between about 59 to $67^{\circ} \mathrm{N}$ but with declining densities in the northern part and a pro- nounced maximum in egg abundance off Southwest Greenland (Fig. 5). 


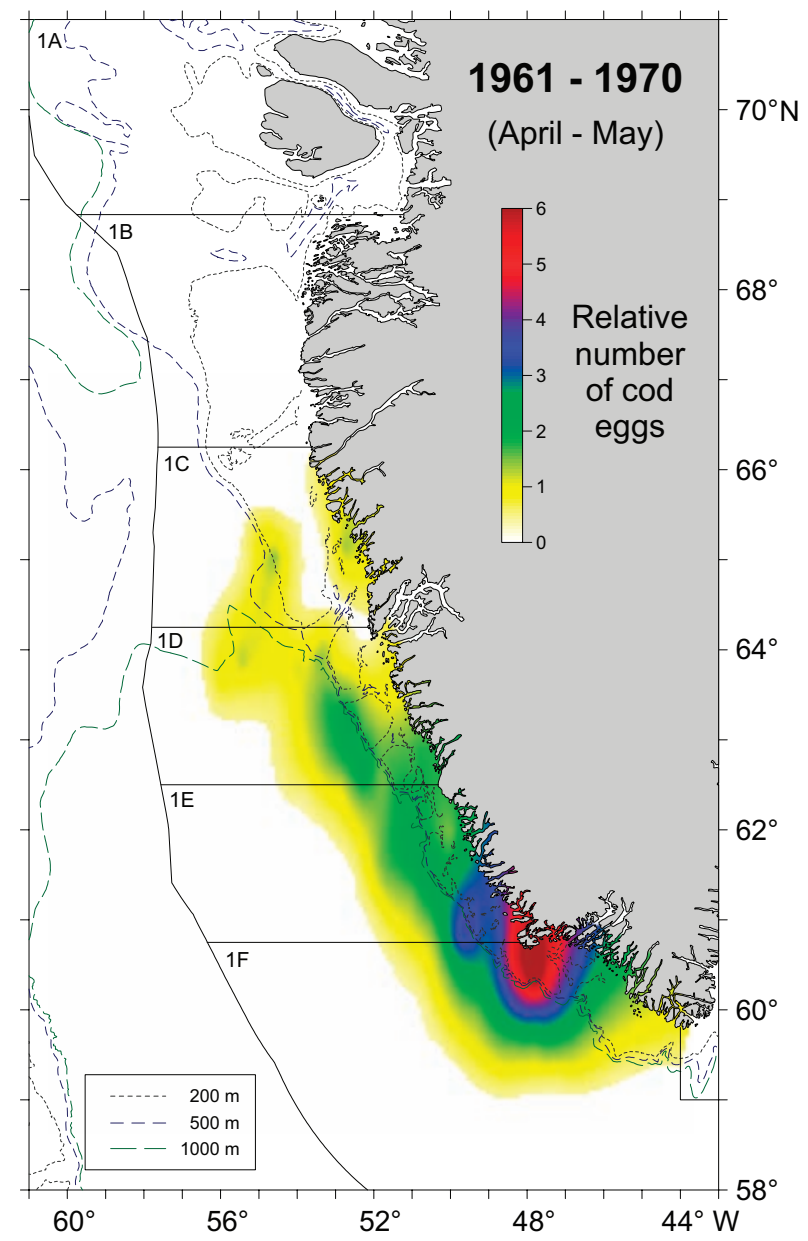

Fig. 5. Average distribution of cod eggs off West Greenland 1961-70 (spring surveys, see Table 1a for details).

The distribution of cod larvae at West Greenland in summer is shown in Figure $6 \mathrm{a}-\mathrm{c}$ by year using all of the information from a total of 33 national and international surveys conducted in the years 1950 to 1984 (Table 1b). A considerable proportion of the larvae was found far away from the coast in those years in which the surveys covered large parts of the Davis Strait and the area west of NAFO Divisions 1C and 1D. This was the case in 1957 in particular, and also notable in 1958, 1959, 1961, 1963 and 1964 (Fig. $6 a, b)$. In the 1970s and 1980s, the area covered by the surveys was substantially reduced and high numbers of larvae were found occasionally at single stations in the vicinity of the fishing banks between 64 and $67^{\circ} \mathrm{N}$ (Fig. 6c).

The restricted survey coverage in many years does not allow firm conclusions about the dispersion of cod larvae over the entire Davis Strait area. It may how- ever be noted that cod larvae were frequently found at the western border of the survey area and that on average the highest larval abundance was observed in the south-western or central part of the Davis Strait in the 1950s and 1960s, respectively (Fig. 7).

In the 1960s, for which both spring and summer survey data are available, the area of highest larval concentrations located in middle of the Davis Strait in June/July (Fig. 7) was about 350 naut. miles away from the centre of the egg distribution at Southwest Greenland in May/June (Fig. 5). According to the mean difference between the midpoints of the sampling periods of about two months (Table 1), this distance would correspond to an average transport of 6 naut. miles per day $(12.5 \mathrm{~cm} / \mathrm{s})$.

\section{Cod eggs and larvae at East Greenland and Ice- land}

Plankton samples covering the entire area from East Greenland to Iceland were available only for 1963. Cod eggs were found in high numbers widely distributed in Southeast and East Greenland waters (5 stations with 4000 to $9000 \mathrm{cod}$ eggs per $30 \mathrm{~min}$ tow), were nearly absent in the Denmark Strait, and were most abundant in the coastal waters west from Iceland where the maximum catch $(78000 \mathrm{cod}$ eggs per 30 min tow) was recorded in May/April (Fig. 8). Cod egg abundance was negligible in June/July in all regions (Table 2a).

Considerable numbers of cod larvae were found in the southwestern part of the Denmark Strait (6 stations with 10 to 90 cod larvae per $30 \mathrm{~min}$ tow) and in offshore waters west from Iceland (3 stations with 10 to 20 cod larvae per $30 \mathrm{~min}$ tow) in June/July, but not in the other regions during this period (Fig. 9). Cod larvae were almost totally absent in the entire survey area in April/May (Table 2b).

The distance between the centre of the larval distribution in the southern Denmark Strait observed in June/July (Fig. 9) and the area of highest egg concentration off Southwest Iceland in April/May (Fig. 8) was about 150 naut. miles. This would be equal to an average drift of 2.5 naut. miles per day $(5.4 \mathrm{~cm} / \mathrm{s})$ taking a difference of two months between the sampling dates into account (Table 2).

\section{Discussion}

It is very difficult, at all if possible, to distinguish the larvae of Atlantic cod (Gadus morhua) from that 

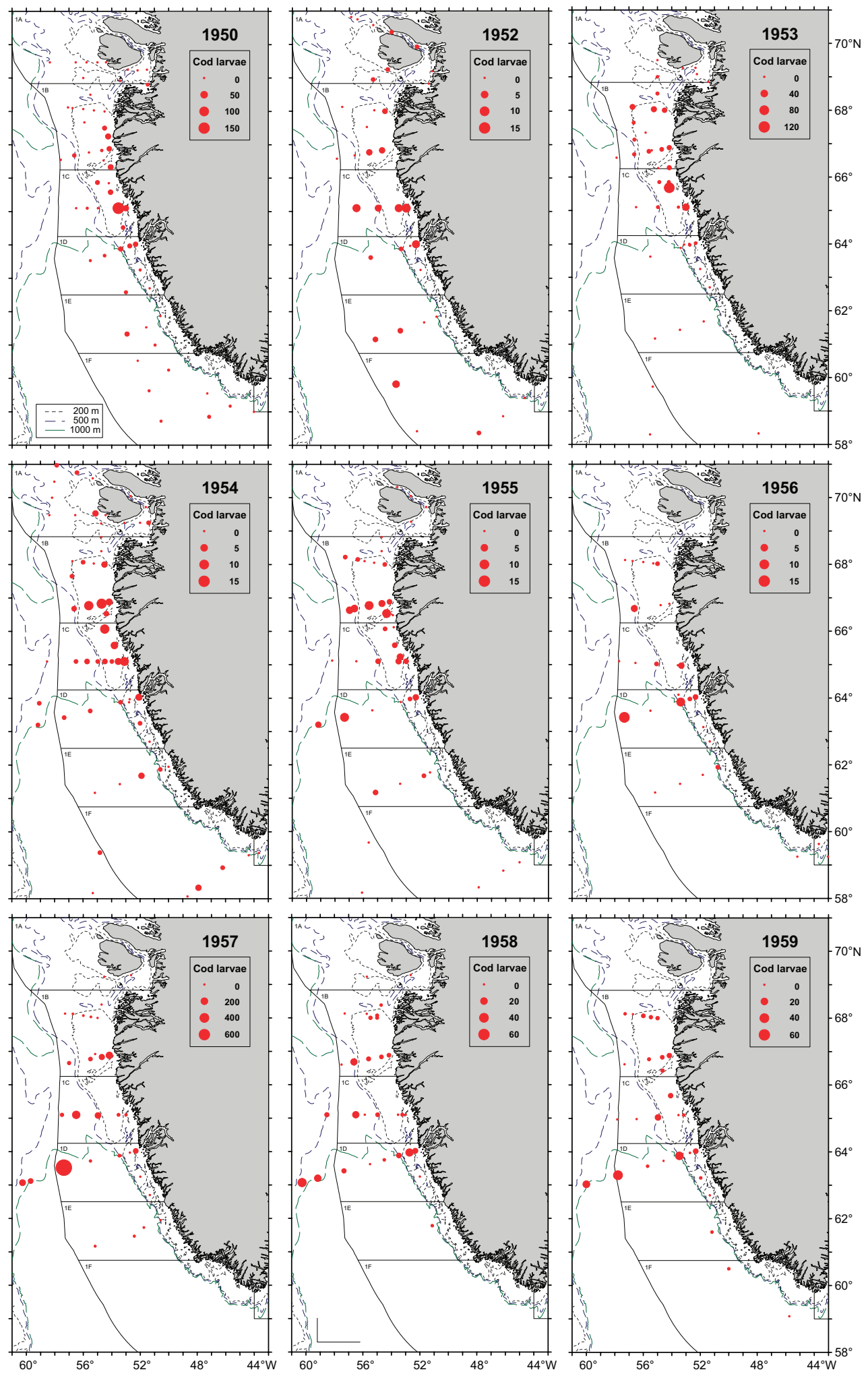

Fig. 6a. Distribution of cod larvae in West Greenland offshore waters 1950 to 1959. Larvae numbers refer to $30 \mathrm{~min}$ haul with $2 \mathrm{~m}$ Stramin ring net. Sampling period: late-May to earlyAugust (see Table $1 \mathrm{~b}$ for details; 1951 no data). 

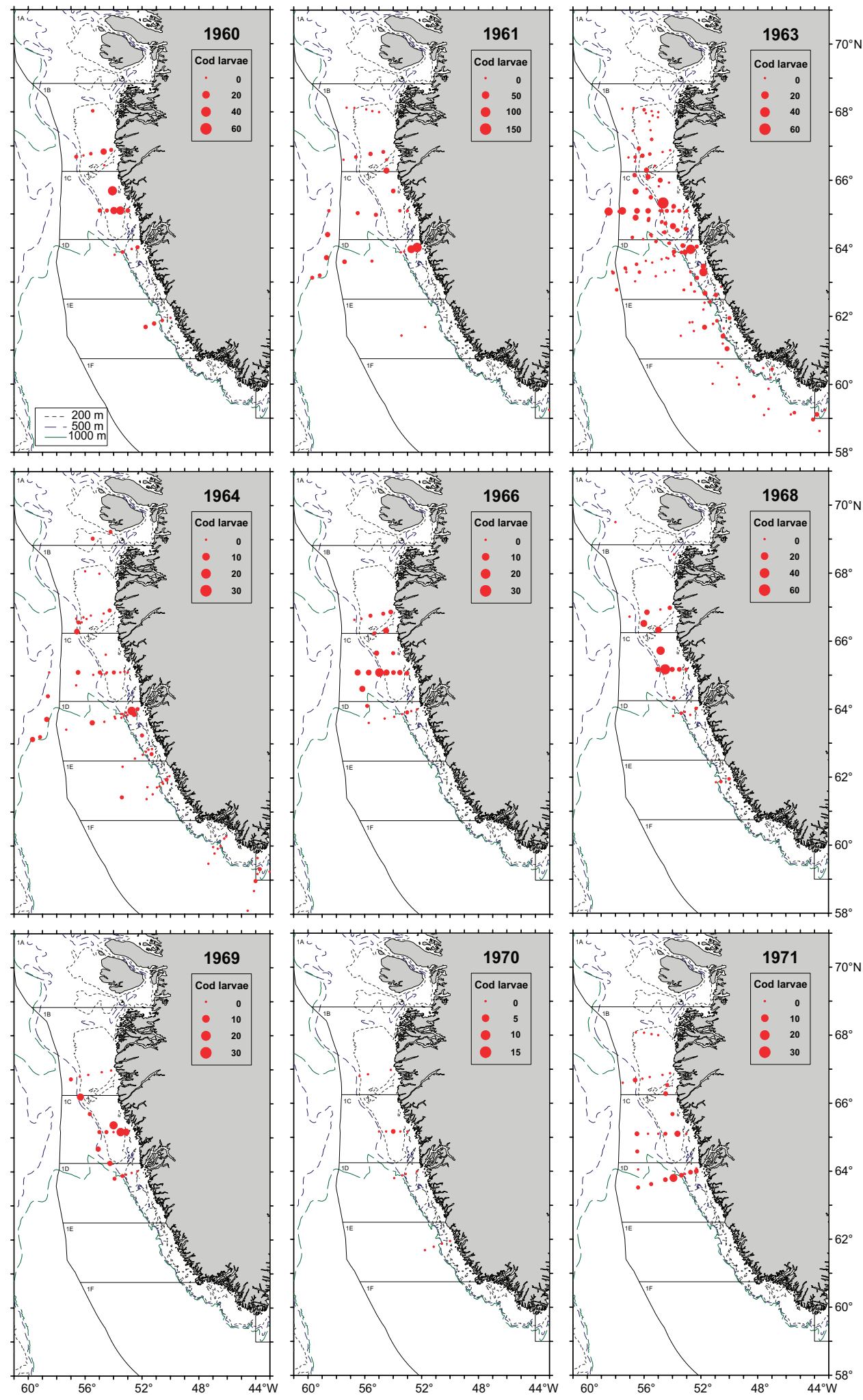

Fig. 6b. Distribution of cod larvae in West Greenland offshore waters 1960 to 1971. Larvae numbers refer to $30 \mathrm{~min}$ haul with $2 \mathrm{~m}$ Stramin ring net. Sampling period: late-May to earlyAugust (see Table 1b for details; 1962, 1965 and 1967 no data). 

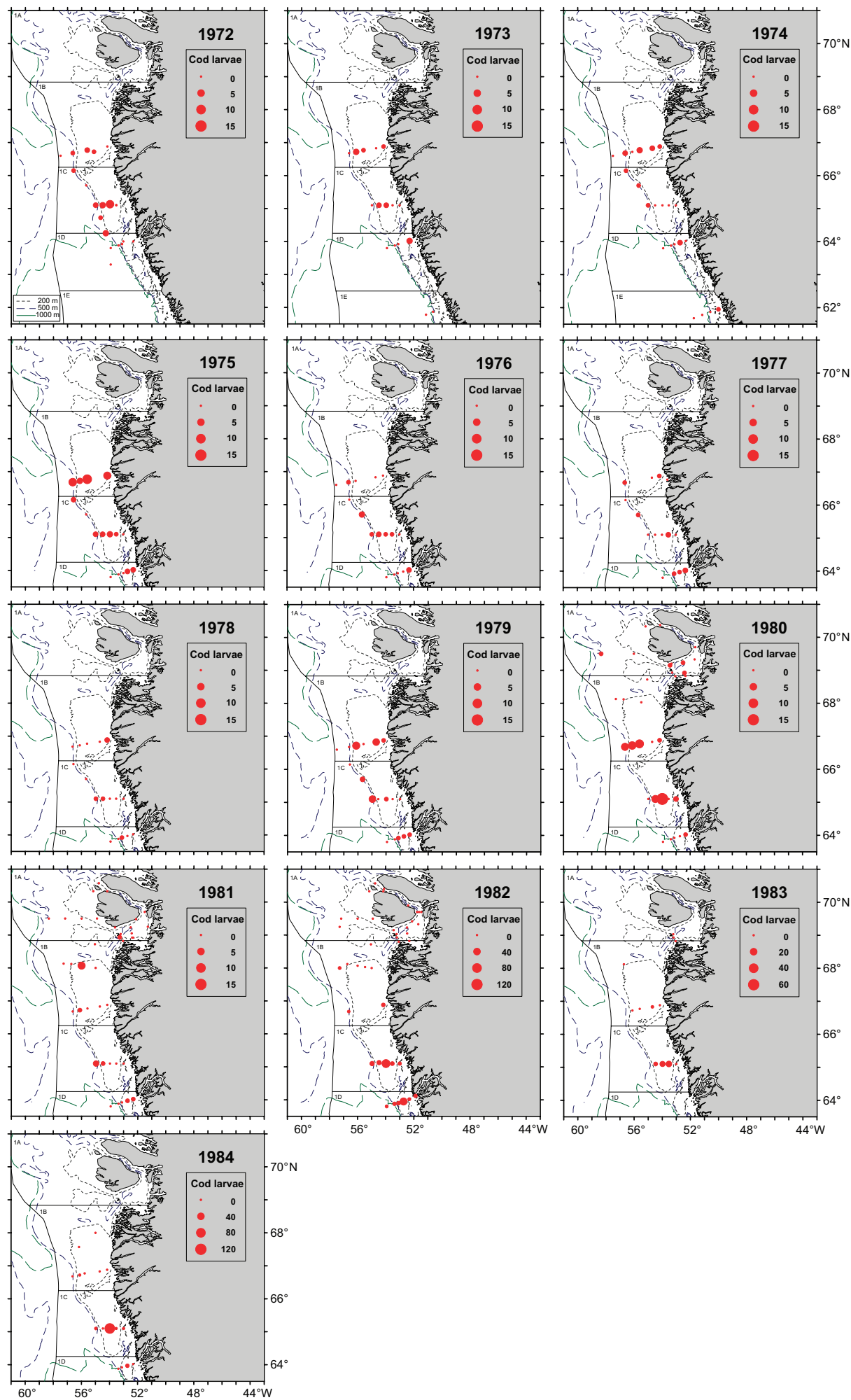

Fig. 6c. Distribution of cod larvae in West Greenland offshore waters 1972 to 1984. Larvae numbers refer to $30 \mathrm{~min}$ haul with $2 \mathrm{~m}$ Stramin ring net. Sampling period: late-May to early-August (see Table $1 \mathrm{~b}$ for details. 

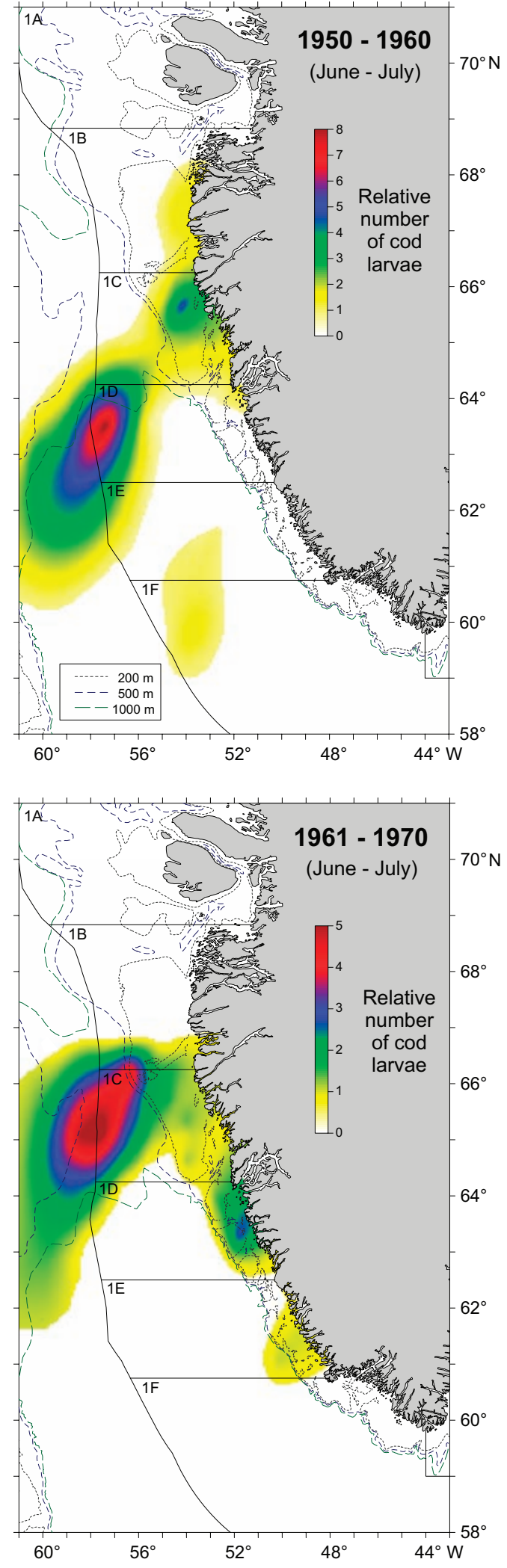

Fig. 7. Average distribution of cod larvae off West Greenland 1950-60 and 1961-70 (summer surveys, see Table $1 \mathrm{~b}$ for details). of Greenland cod (Gadus ogac) (Andersen et al. 1994) and this was not attempted in the sample analysis. Greenland cod is common in inshore areas all along the West Greenland coast from about $60^{\circ}$ to $73^{\circ} \mathrm{N}$ but is absent in East Greenland. For the larvae found offshore it can be assumed that they are predominantly Atlantic cod because Greenland cod is only found in the fjords and coastal areas. Furthermore, Greenland cod spawns earlier (February to March) than Atlantic cod (March to April) and has demersal eggs, which are not transported to the open sea by the currents (Hansen 1949).

Direct observations on spawning of Atlantic cod at West Greenland are scarce. Jonsson (1959) found that $50 \%$ of the mature fish were spawning and $38 \%$ had finished spawning in the end of April, and Bratberg (1965) noted that $40 \%$ of cod caught in the middle of April had not yet finished spawning. In 1961 and 1966 spawning was at its peak by the end of March and the beginning of April (Meyer, 1963, 1967), and a high proportion of spawning cod were observed in March 1967 during a Union of Soviet Socialist Republic survey (Konstantinov and Noskow 1968). However, information on cod maturity from a Portuguese survey in 1968 revealed that spawning was nearly completed by June except for a small fraction of males, which were in running condition (Diaz 1969), and Serebryakow (1967) also reported spawning as late as June. Spawning locations were observed at the offshore slope of Fyllas Bank $\left(64^{\circ} \mathrm{N}\right)$ in $120 \mathrm{~m}$ depth at a temperature of $1.5^{\circ} \mathrm{C}$ (Jonsson 1959), but more frequently west of the various fishing banks further south below $350 \mathrm{~m}$ depth in the warmer Atlantic water (Meyer 1963, 1967; Meyer and Lenz 1972; Konstantinov and Noskow 1968).

At East Greenland, spawning cod were observed from March to June (Meyer 1958, 1962, 1963; Jonsson 1959, 1961, 1975; Serebryakov 1967) along the offshore slope of the shelf from about $62^{\circ}$ to $66^{\circ} \mathrm{N}$. Spawning depth ranged from 170 to $400 \mathrm{~m}$ (Jonsson 1959; Meyer 1963) at which temperatures were between $3.2^{\circ}$ and $5.2^{\circ} \mathrm{C}$ (Jonsson 1959, 1961). The results from the ichthyoplankton surveys presented in this study confirm the observations on the timing of cod spawning at West and East Greenland from the studies cited above.

Cod egg abundance data from the NORWESTLANT surveys in 1963 including both Stramin and Hensen net samples emphasize a high importance of the spawning area at East Greenland. This was not recognized by Hansen (1968) who considered only the 


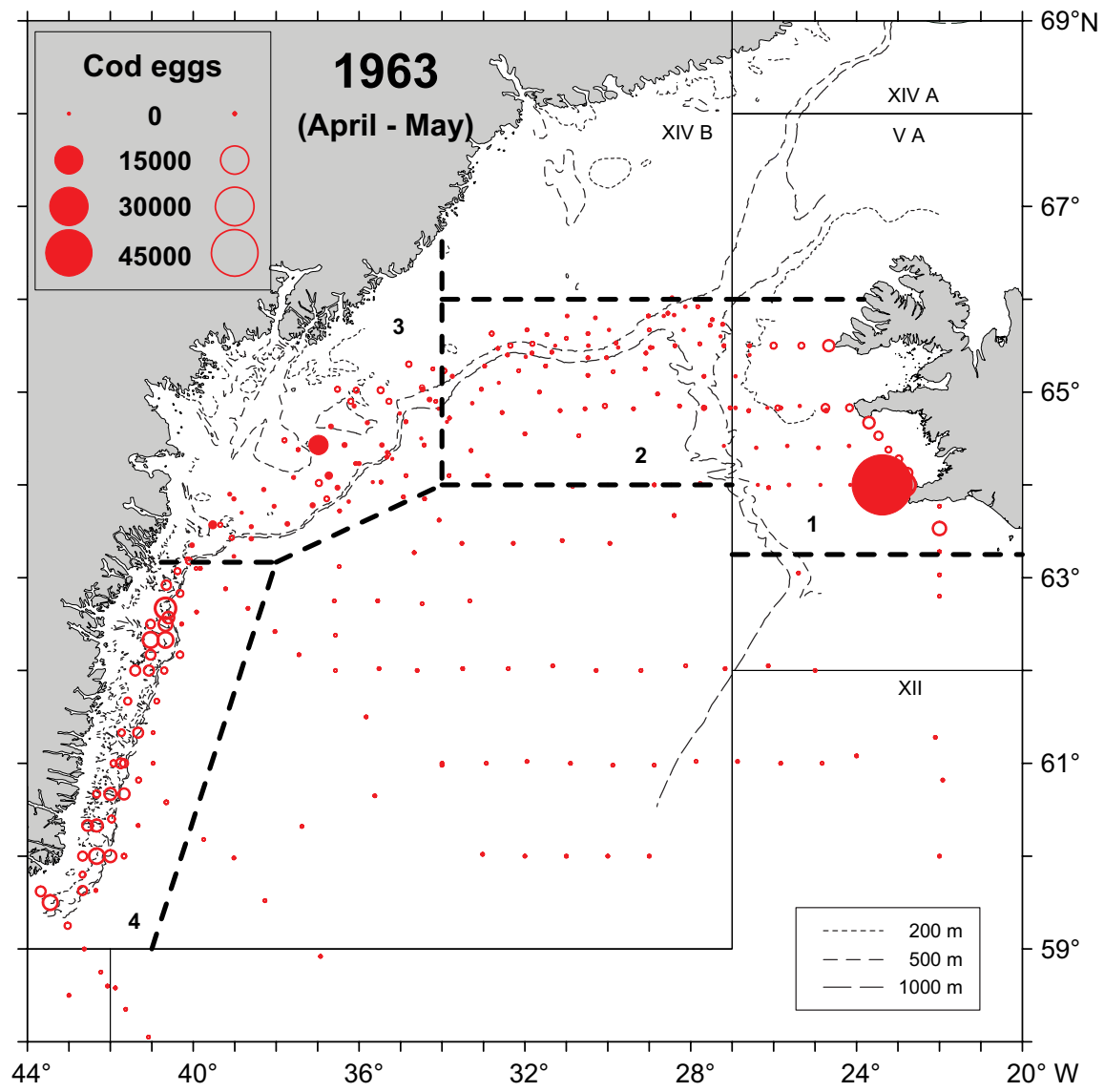

Fig. 8. Distribution of cod eggs off East Greenland and Iceland in April/May 1963 (see Table 2a for details). Egg numbers refer to 30 min haul with $2 \mathrm{~m}$ Stramin ring net (Filled symbols: original hauls with Stramin ring net, open symbols: Hensen net catches converted to Stramin standard haul).

Stramin net samples but is in accordance with the findings of Serebryakov (1967) who analysed Hensen net samples and reported that there were substantially more cod eggs off East Greenland than off West Greenland.

During June/July cod larvae were predominantly found between 63 and $67^{\circ} \mathrm{N}$ at West Greenland, which is about 350 to 600 nautical miles away from the spawning areas at Southwest and Southeast Greenland as identified by the egg distribution in May/April. Such a drift pattern is in agreement with the direction of the currents around South Greenland and would require an average transport of about 6 to 10 nautical miles per day $(12.5$ to $21.4 \mathrm{~cm} / \mathrm{s})$ assuming that the distance is covered within two months (Fig. 10). Current data compiled by Serebryakov (1967) revealed mean velocities of $30 \mathrm{~cm} / \mathrm{s}$ in the area between $67^{\circ} \mathrm{N}$ at East Greenland and $64^{\circ} \mathrm{N}$ at West
Greenland and $10 \mathrm{~cm} / \mathrm{s}$ at West Greenland between 64 and $67^{\circ} \mathrm{N}$, which are sufficient to explain the difference between the egg and the larval distribution presented in this study. A considerable proportion of cod larvae found in the south-western part of the Davis Strait, as observed in a couple of years in the 1950's and 1960 's, was likely transported further towards the coast of Labrador based on the current regime in this region (Serebryakov 1967; Dickson and Brander 1993) and must be considered as lost to the recruitment of cod at West Greenland (Fig. 10).

At Iceland, cod spawn off the southwest coast from the end of March to the beginning of May with a peak usually at the end of April (Jonsson 1982). Spawning takes places at a depth below $35 \mathrm{~m}$ where temperatures are rarely below $6^{\circ} \mathrm{C}$. The eggs and larvae drift from the spawning area by clockwise currents to the northwest, north, and the northeast coast 


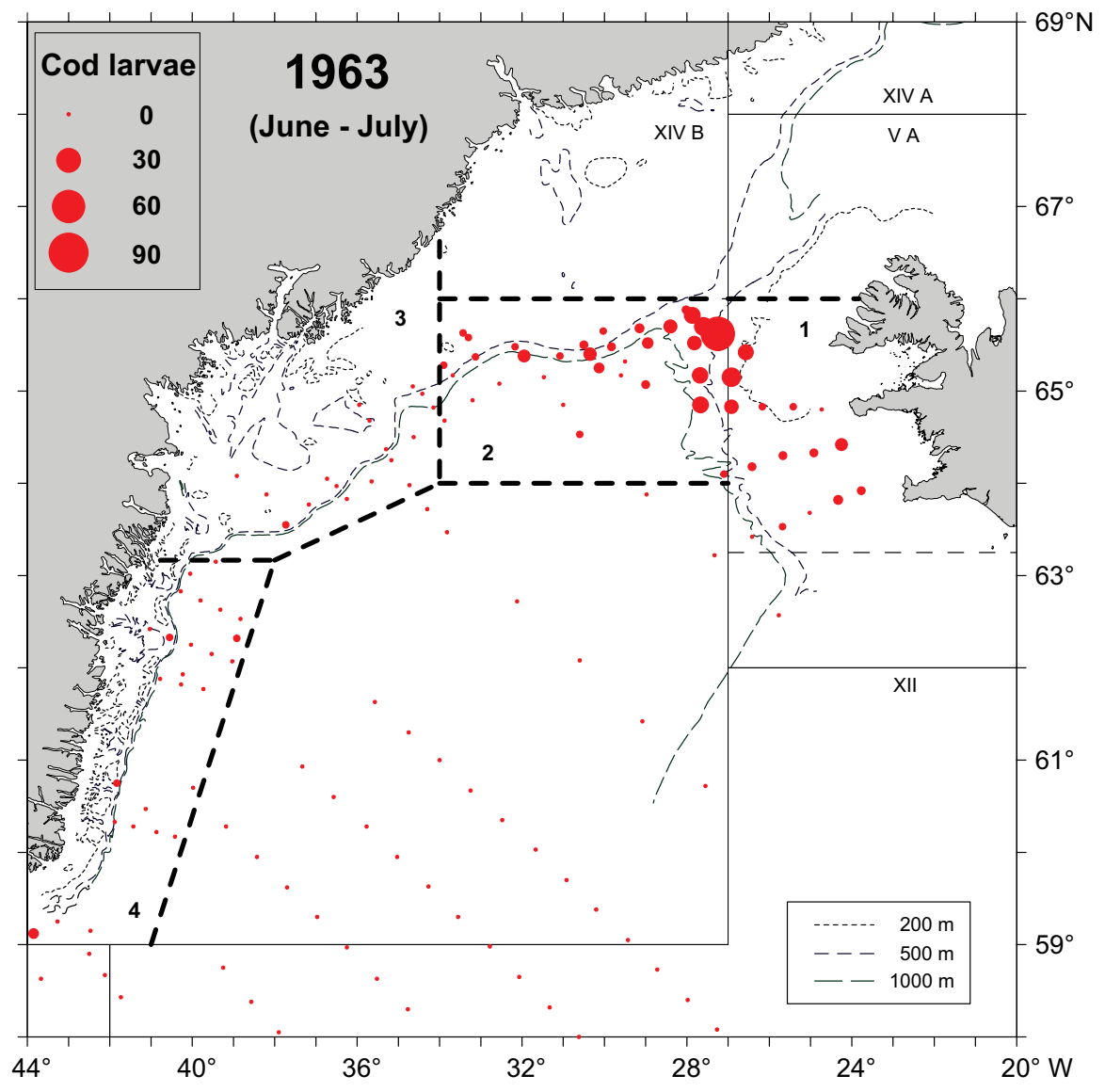

Fig. 9. Distribution of cod larvae off East Greenland and Island in June/July 1963 (see Table $2 \mathrm{~b}$ for details). Larvae numbers refer to $30 \mathrm{~min}$ haul with $2 \mathrm{~m}$ Stramin ring net.

of Iceland and in some years a considerable fraction may also drift across the Denmark Strait to East Greenland waters (Astthorsson et al. 1994).

Tåning (1943) originally were described the drift of cod larvae from Southwest Iceland to East Greenland, and cod larvae were observed during the June/ July 1963 NORWESTLANT surveys in the southern Denmark Strait as described in this study. Herman and Thomsen (1946) reported a mean velocity of the currents in that region of $20 \mathrm{~cm} / \mathrm{s}$, which would result in a transport over a distance of 300 nautical miles from the Denmark Strait to the East Greenland coast within one month (Fig. 10).

Icelandic and East Greenland waters have been covered by pelagic trawl surveys carried out by Iceland annually since 1970 in August/September. In some years, notably 1973 and 1984, high numbers of 0-group cod were found southwest from the Denmark Strait (Astthorsson et al. 1994). Settling areas of 0group cod at Greenland are not precisely known. For year-classes that are indicated to be mainly of Icelandic origin, e.g. that of 1984, it appears reasonable to assume that settling occurred at East Greenland and the southernmost part of West Greenland because haddock, which is rare at Greenland but spawns in Icelandic waters, also settled in these areas (Hovgård and Messtorff MS 1987). However, nursery areas of Atlantic cod at Greenland can have a wider extension than the primary settling areas as the 1984 year-class was abundant and widely distributed from East Greenland to about $64^{\circ} 30^{\prime} \mathrm{N}$ at West Greenland at age 3 (Anon. 1990), which implies a subsequent transport and migration of the early juveniles.

The distribution patterns of cod fry in Greenland waters presented in this study can serve as a basis for 


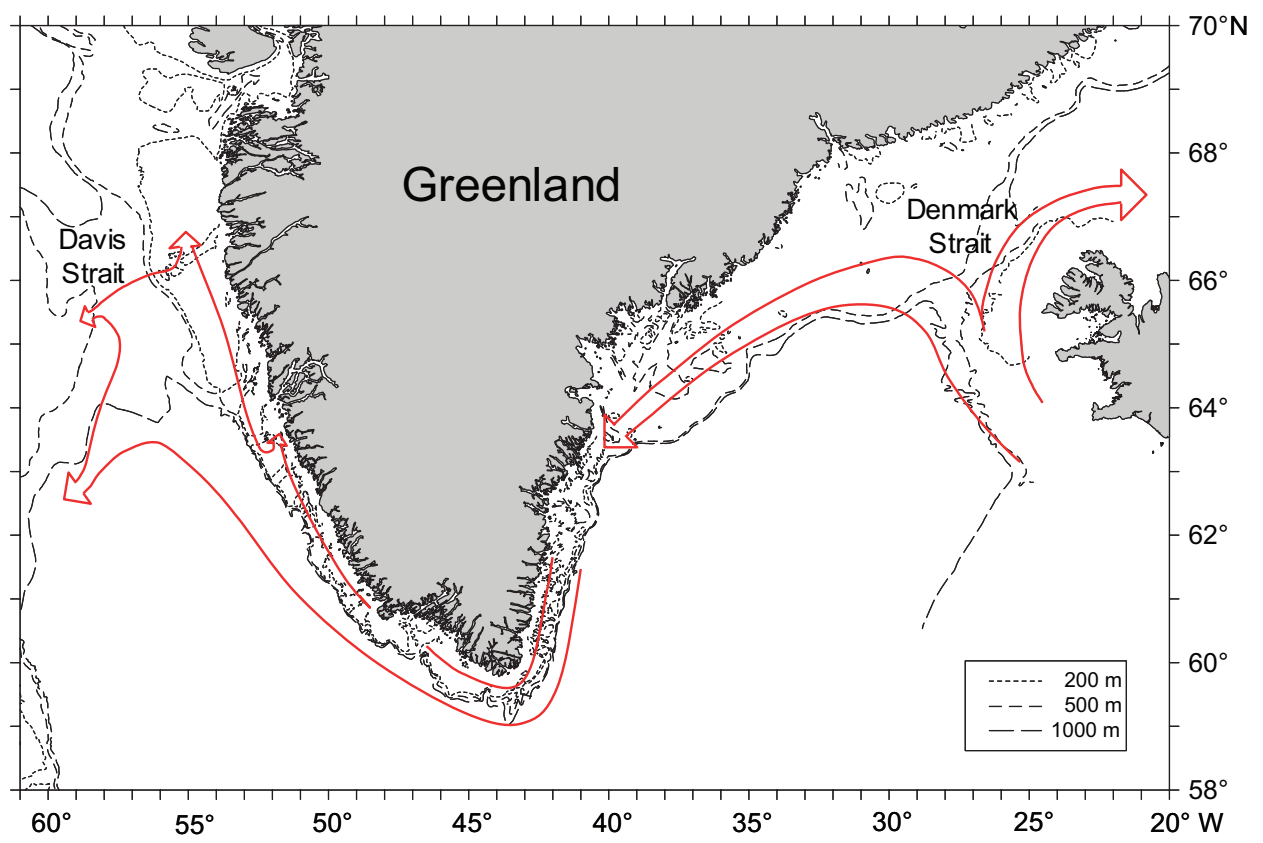

Fig. 10. Generalized pattern of cod egg and larval transport in the Iceland - Greenland area.

simulations using hydrodynamic models, which may provide a more realistic and detail view of transport processes than a comparison of the observed egg and larval distributions linked to a generalized current regime can do. In the recent years, temperature conditions have been favourable at East and Southwest Greenland (Borovkov and Stein MS 2001, Buch et al. MS 2002) and spawning stock biomass of Icelandic cod as well as 0-group abundance in Icelandic waters has been at or even above the levels reported for the 1980s, but cod have not been observed in Greenland waters in considerable numbers yet (Anon. 2002). Although changes in survival related to other factors than temperature might be at play, larval drift across the Denmark Strait appears to be crucial for a short-term recovery of the cod stock in Greenland offshore waters, and model simulations using actual wind fields encountered during the egg and larval period may help to explain why this has obviously not taken place in recent years.

\section{References}

ANDERSEN, O. G. N., J. R. NIELSEN, and E. L. B. SMIDT. 1994. Description and comparison of eggs and yolk-sac larvae of Greenland cod, Atlantic cod and Polar cod from West Greenland waters. J. Northw. Atl. Fish. Sci., 16: $19-32$.

ANON. 1968. Environmental surveys NORWESTLANT 13, 1963. ICNAF Spec. Publ. No. 7, Part IV: Biological Data Record.
1990. Report of the Working Group on Cod Stocks off East Greenland. ICES C.M. Doc. No. Assess:12, 51 p.

2002. Report of the North-Western Working Group. ICES CM Doc., No. ACFM:20, 416 p.

ASTTHORSSON, O. S., A. GISLASSON, and A. GUDMUNDSDOTTIR. 1994. Distribution, abundance, and length of pelagic juvenile cod in Icelandic waters in relation to environmental conditions. ICES Mar. Sci. Symp., 198: 529-541.

BIESTER, E. and W. MAHNKE. 1963. Untersuchungen über das Vorkommen von Fischeiern and Fischlarven im Gebiet Westgrönland 1961 bis 1963 und zwischen den Färöern und Kap Farwell 1961 und 1962. FischereiForschung 1(1): 37-46.

BOROVKOV, V. A. and M. STEIN. MS 2001. Recruitment of West Greenland cod - Modelling different cause-effect regimes. NAFO SCR Doc., Serial No. N4373, 8 p.

BRATBERG, E. 1965. Norwegian investigations on cod eggs in West Greenland, 1963. Annls. Biol., 20: 115.

BUCH, E., S. A. HORSTED, and H. Hovgård. 1994. Fluctuations in the occurrence of cod in Greenland waters and their possible causes. ICES Mar. Sci. Symp., 198: $158-174$.

BUCH, E., M. H. NIELSEN, and S. A. PEDERSEN. MS 2002. Ecosystem variability and regime shift in West Greenland waters. NAFO SCR Doc., Serial No. N4617, $19 \mathrm{p}$.

CHILÈS, J.-P. and P. DELFINER. 1999. Geostatistics: Modeling spatial uncertainty. John Wiley \& Sons, New York. 695 p.

DIAZ, M. L. 1969. Portuguese research report, 1968. ICNAF Redbook 1969, Part II: 76-88. 
DICKSON, R. R. and K. BRANDER. 1993. Effects of a changing windfield on cod stocks of the North Atlantic. Fish. Oceanogr., 2(3/4): 124-153.

ERNST, P. 1970. Untersuchungen über das Vorkommen von Fischeiern und Fischlarven der wichtigsten Nutzfischarten vor Westgrönland und in der Irminger See im Jahre 1969. Fischerei-Forschung, 8(1): 7-14.

HANSEN, P. M. 1949. Studies on the biology of the cod in Greenland waters. ICES Rapp. Proc.-Verb., 123: 1-77.

1968. Report on cod eggs and larvae. ICNAF Spec. Publ., No. 7, Part I: 127-137.

HANSEN, H. and E. BUCH. 1986. Predicting year-class strength of Atlantic cod (Gadus morhua) off West Greenland. NAFO Sci. Coun. Studies, 10: 7-11.

HERMANN, F. and H. THOMSEN. 1946. Drift bottle experiments in the Northern Atlantic. Medd. Komm. Dan. Fisk. Havunders., Ser. Hydrogr., 3(4): 87 pp.

HORSTED, S.A. 2000. A review of the cod fisheries at Greenland, 1910-1995. J. Northw. Atl. Fish. Sci., 28: 1-112.

HOVGÅRD, H. and S. CHRISTENSEN. 1990. Population structure and migration patterns of Atlantic cod at West Greenland waters based on tagging experiments from 1946 to 1964. NAFO Sci. Coun. Studies, 14: 45-50.

HOVGÅR, H. and J. MESSTORFF. MS 1987. Is the West Greenland cod mainly recruited from Icelandic waters? An analysis based on the use of juvenile haddock as an indicator of larval drift. NAFO SCR Doc., No. 31, Serial No. N1315, 18 p.

JENSEN, A. S. 1909a. Rapport til Indenrigsministeriet over Briggen "Tjalfe"s praktisk-videnskabelige Fiskeriekspedition til Grønland. Foreløbig beretning om undersøgelser i 1908. Beretn. Og Kundg. Vedr. Kolon. $i$ Grønl. 1909, 2: 11-12.

1909b. Rapport til Indenrigsministeriet over Briggen "Tjalfe"s praktisk-videnskabelige Fiskeriekspedition til Grønland. Foreløbig beretning om undersøgelser i 1909. Beretn. Og Kundg. Vedr. Kolon. i Grønl. 1909, 2: 79106.

1926. Investigations of the "DANA" in West Greenland waters, 1925. ICES Rapp. Proc.-Verb., 39: 85-102.

JONSSON, E. 1982. A survey of spawning and reproduction of the Icelandic cod. Rit Fiskideildar, 6(2): 1-42.

1959. Icelandic cod investigations in Southwest and Southeast Greenland waters, 1957. Annls. Biol., 14: 115118 .

1961. On the spawning stocks of cod in East Greenland and Iceland waters, 1959. Annls. Biol., 16: 130135 .

1975. On the spawning of cod in East Greenland waters in 1973. Annls. Biol., 30: 79-80.

KONSTANTINOV, K. G. and A. S. NOSKOW. USSR research report, 1967. ICNAF Redbook 1968, Part II: 102-125.

MAHNKE, W. 1967a. Untersuchungen über das Vorkommen von Fischeiern und Fischlarven der wichtigsten Nutzfischarten vor Westgrönland und zwischen den Färöern und Kap Farwell in den Jahren 1964 und 1965. Fischerei-Forschung, 5(1): 75-82.

1967b. Untersuchungen über das Vorkommen von Fischeiern und Fischlarven der wichtigsten Nutzfischarten vor Westgrönland, Labrador und in der Irminger See im Jahre 1966. Fischerei-Forschung, 5(2): $11-15$.

MEYER, A. 1958. Greenland cod, German investigations, 1956. Annls. Biol., 13: 137-139.

1962. Greenland cod, German investigations, 1960. Annls. Biol., 17: 136-139.

1963. Greenland cod, German investigations, 1961. Annls. Biol., 18: 114-118.

1967. German research report, 1966. ICNAF Redbook 1967 Part II: 48-55.

MEYER, A. and W. LENZ. 1972. German research report, Subarea 1 and East Greenland. ICNAF Redbook 1972, Part II: $37-42$.

RÄTZ, H.-J. 1999. Structures and changes of the demersal fish assemblage off Greenland. NAFO Sci. Coun. Studies, 32: 1-15.

RÄTZ, H.-J., M. STEIN, and J. LLORET. 1999. Variation in growth and recruitment of Atlantic cod (Gadus morhua) off Greenland during the second half of the twentieth century. J. Northw. Atl. Fish. Sci., 25: 161-170.

RASMUSSEN, B. 1959. On the migration pattern of the West Greenland stock of cod. Annls. Biol., 14: 123-124.

SEREBRYAKOV, V. P. 1967. Cod reproduction in the Northwest Atlantic. PNIRO papers, 20: 205-242 (in Russian, Translation series No. 1133 Fisheries Research Board of Canada 1968).

SCHOPKA, S. A. 1993: The Greenland cod (Gadus morhua) at Iceland 1941-1990 and their impact on assessments. NAFO Sci. Coun. Studies, 18: 81-85.

SCHOPKA, S. A. 1994: Fluctuations in the cod stock off Iceland during the twentieth century in relation to changes in the fisheries and environment. ICES Mar. Sci. Symp., 198: $175-193$.

SHEPHERD, J. G. and J. POPE. 1993. Alternative methods for the estimation of immigration to the Icelandic cod stock. Fish. Oceanogr., 2(3/4): 254-259.

TÅNING, A. V. 1943. Cod. Drift of larval of larval stages across the Denmark Strait. Annls. Biol., 1: 95-96. 